\title{
Micro-Tensile and Compression Strength of Scots Pine Wood and Comparison with Standard- Size Test Results
}

\section{Mikrovlačna i mikrotlačna čvrstoća škotske borovine i usporedba s rezultatima ispitivanja čvrstoće na uzorcima standardne veličine}

\author{
Original scientific paper • Izvorni znanstveni rad \\ Received-prispjelo: 22. 8. 2016. \\ Accepted-prihvaćeno: 11. 5. 2017. \\ UDK: $630 * 812.72 ; 630 * 812.76 ; 674.032 .475 .442$ \\ doi:10.5552/drind.2017.1639
}

\begin{abstract}
The goal of this study was to investigate the tensile and compression strength of Scots pine wood (Pinus sylvestris L.) using micro- and standard-sized test specimens. In the standard-and micro-sized specimens, tensile strength was evaluated as $76.9 \mathrm{MPa}$ and $91.5 \mathrm{MPa}$ and compression strength as $43.8 \mathrm{MPa}$ and $36.3 \mathrm{MPa}$, respectively. The results showed that the compression strength of the micro-sized specimens was lower compared to the standard-sized specimens, while the tensile strength was higher in the micro-sized specimens. With the exception of the effect of specimen size and individual tree interaction on tensile strength, statistically significant effects were found for specimen size, individual trees and the interactions of the size and trees on the tensile and compression strength. Moreover, regression analyses indicated a positive linear regression between the strength of micro- and standard-sized specimens. Micro-sized specimens can be used to estimate the tensile and compression strength of Scots pine wood, when it is not possible to obtain standard-size specimens.
\end{abstract}

Key words: micro-sized specimens, standard-sized specimens, tensile strength, compression strength

\begin{abstract}
SAŽETAK • Cilj istraživanja bio je usporediti vlačnu i tlačnu čvrstoću borovine (Pinus sylvestris L.) određenu na mikrouzorcima i na ispitnim uzorcima standardne veličine. Vlačna čvrstoća borovine određena na ispitnim uzorcima standardne veličine iznosila je 76,9 MPa, a na mikrouzorcima 91,5 MPa, dokje tlačna čvrstoća borovine izmjerena na standardnim ispitnim uzorcima bila 43,8 MPa, a na mikrouzorcima 36,3 MPa. Rezultati su pokazali da je tlačna čvrstoća borovine određena na mikrouzorcima manja od tlačne čvrstoće izmjerene na ispitnim uzorcima standardne veličine, dok je vlačna čvrstoća borovine izmjerena na mikrouzorcima veća od vlačne čvrstoće standardnih uzoraka. Uz izuzetak interakcijskog utjecaja veličine ispitnog uzorka i pojedinačnog stabla od kojega su uzorci izrađeni na vlačnu čvrstoću, statistička analiza dobivenih podataka pokazala je signifikantan utjecaj veličine ispitnog uzorka, pojedinačnog stabla od kojega je izrađen ispitni uzorak i interakcije veličine uzorka $i$

\footnotetext{
${ }^{1}$ Authors are associate professor and master student at Duzce University, Faculty of Forestry, Forest Product Engineering Department, Duzce, Turkey. ${ }^{2}$ Authors are professor and associate professor at Istanbul University, Faculty of Forestry, Forest Product Engineering Department, Istanbul, Turkey.

Autori su izvanredni profesor i student diplomskog studija Sveučilišta u Duzceu, Šumarski fakultet, Odjel za inženjerstvo drvnih proizvoda, Duzce, Turska. ${ }^{2}$ Autori su profesor i izvanredni profesor Sveučilišta u Istanbulu, Šumarski fakultet, Odjel za inženjerstvo drvnih proizvoda, Istanbul, Turska.
} 
stabla od kojega je uzorak izrađen na vlačnu i tlačnu čvrstoću borovine. Usto, regresijska je analiza podataka pokazala pozitivnu linearnu regresiju između čvrstoće mikrouzoraka i čvrstoće ispitnih uzoraka standardne veličine. Iz toga se može zaključiti da se za procjenu vlačne i tlačne čvrstoće škotske borovine mogu upotrijebiti mikrouzorci kad god izrada ispitnih uzoraka standardne veličine nije moguća.

Ključne riječi: mikrouzorci, ispitni uzorci standardne veličine, vlačna čvrstoća, tlačna čvrstoća

\section{INTRODUCTION}

\section{UVOD}

Scots pine is an important tree species native to Eurasia. In Turkey, it covers about $5 \%$ (738 000 ha) of the total Turkish forestland. Moreover, it exhibits superior technological properties and a high potential for utilization. In order to determine the mechanical properties of wood, the approach has been to use structuralsize and small-size clear specimens. In recent years, micro-size specimens have been used to evaluate the mechanical properties of earlywood and latewood sections, wood strands, and fibers (Plagemann, 1982; Hunt et al., 1989; Groom et al., 2002; Mott et al., 2002; Deomano and Zink-Sharp 2004; Cai et al., 2007; Hindman and Lee 2007; Jeong 2008; Jeong et al., 2009).

In previous studies on micro-sized testing, researchers used various specimen dimensions and loading rates according to the purpose of the study. Deomano and Zink-Sharp (2004) investigated the bending properties of southern yellow pine (Pinus spp.), sweet gum (Liquidambar styraciflua L.), and yellow poplar (Liriodendron tulipifera L.) wood. Samples of $25 \times 5.0$ $\times 0.6 \mathrm{~mm}$ flakes were used to calculate the modulus of rupture (MOR) and modulus of elasticity (MOE) of these wood species, with the loading rate of $2.54 \mathrm{~mm} /$ min. Hindman and Lee (2007) measured the bending and tensile properties of both earlywood and latewood sections of loblolly pine (Pinus taeda) strands. The dimensions of the bending test samples were $33.0 \times 11.0$ $\times 0.68 \mathrm{~mm}$ and of the tensile test samples $60 \times 0.66 \times$ $4.58 \mathrm{~mm}$ for earlywood, and $60 \times 0.66 \times 3.3 \mathrm{~mm}$ for latewood. The loading rate was $0.127 \mathrm{~mm} / \mathrm{min}$.

The tensile properties of willow (Salix spp.), yellow poplar (Liriodendron tulipifera L.), red oak (Quercus spp.) and loblolly pine (Pinus taeda) wood strands were investigated by Cai et al., (2007). Hunt et $a l .$, (1989) conducted tensile testing to determine the tensile strength and tensile modulus of yellow poplar strands (Liriodendron tulipifera L.) with a $2224 \mathrm{~N}$ load cell at a test speed of $1.9 \mathrm{~mm} / \mathrm{min}$. Their study revealed that the average tensile strength and tensile modulus was $70.3 \mathrm{MPa}$ and $11.8 \mathrm{GPa}$, respectively.

Zink-Sharp and Price (2006) determined the compression strength of sweetgum (Liquidambar styraciflua L.), yellow poplar (Liriodendron tulipifera L.), and red maple (Acer rubrum) wood species using 1 $\times 1 \times 4 \mathrm{~mm}$ specimens. The test was conducted at $12 \%$ moisture content (MC) with a loading speed of 0.029 $\mathrm{mm} / \mathrm{min}$. They found that the compression strength of sweetgum, yellow poplar and red maple wood were 39.2, 33.5 and 41.6 MPa, respectively.

Micro-size specimens can be used to determine the mechanical properties of wood, when it is not pos- sible to obtain standard-size test specimens. In order to avoid damaging the wood in various applications, the mechanical properties can be determined by using micro-size test specimens. Furthermore, the test specimens of structural wood material can be taken periodically and their mechanical properties can be determined. In this way changes in the mechanical properties of wood can be observed over time. With the development of micro-size tests, the strength losses due to exposure time can be determined for structural wood applications. This information can provide a solid base for a true assessment of the necessity of wooden structure renewal.

The mechanical properties of specimens are dependent on the specimen dimensions. This phenomenon is called size effect (Weibull, 1939). According to the theory of size effect (weakest link theory), the strength is dependent on the size of highly stressed volume. The basis for this theory is that there is a greater probability that a region of low strength will occur in a member of large volume than in a member of small volume. This region of low strength is assumed to cause complete failure of the member (Weibull, 1939).

The analysis of the factors influencing the size effect of strength and elastic properties is very complex and a number of hypotheses have been developed in the last 100 years. To simplify the matter, it is helpful to consider different species and different mechanical tests separately (Schotzhauer et al., 2015). Madsen and Buchanan (1986) also stated that the size effect is dependent on wood species.

There is limited information concerning the comparison of tensile and compression strength of microand standard-size specimens. In previous studies, researchers compared their findings of micro-size test with values published in Wood Handbook for standard-size specimens (Zink-Sharp and Price, 2006; Cai et al., 2007). Cai et al., (2007) found that the tensile strength of willow, yellow poplar, red oak and loblolly pine strands, was, respectively, $31.1 \%, 44.2 \%, 36.2 \%$ and $73.4 \%$ lower than that of standard-size specimens. Zink-Sharp and Price (2006) stated that the compression strength of the micro-size specimens was close to but lower than handbook values for sweet gum, yellow poplar and maple wood species. This approach of comparing the values obtained from different trees is not valid for obtaining information about the presence of a correlation between micro-size and standard-size specimens. It is recognized that the tree age and growth conditions, such as the climate, soil characteristics, slope, and altitude, affect the annual ring width and the mechanical properties of wood. The goal of this paper is, therefore, to evaluate the tensile and compression strength of micro-size Scots pine (Pinus sylvestris L.) wood and investigate the 
correlation between micro- and standard-size specimens that are taken from the same tree.

\section{MATERIALS AND METHODS 2. MATERIJALI I METODE}

\subsection{Materials}

\subsection{Materijali}

Sample trees were harvested from the Bolu Forest Enterprises in the northwestern part of Turkey. Eight trees with straight stems were selected as sample trees. Table 1 shows the properties of the sample trees and sampling area.

Logs of $3 \mathrm{~m}$ in length were cut from each tree at a height of $0.30 \mathrm{~m}$, and then 6-cm-thick planks, including the central pith, were cut from these logs. The micro- and standard-size test specimens were prepared from these planks. The cutting plan of the test specimens is shown in Figures $1 \mathrm{a}$ and $1 \mathrm{~b}$. All of the specimens were conditioned in a climate chamber at a temperature of $20{ }^{\circ} \mathrm{C}$ and a relative humidity of $65 \%$ for three weeks to reach the target moisture content of $12 \%$ prior to testing.

\subsection{Methods}

\subsection{Metode}

Specimens were cut according to International Organization for Standardization (ISO) in order to de-

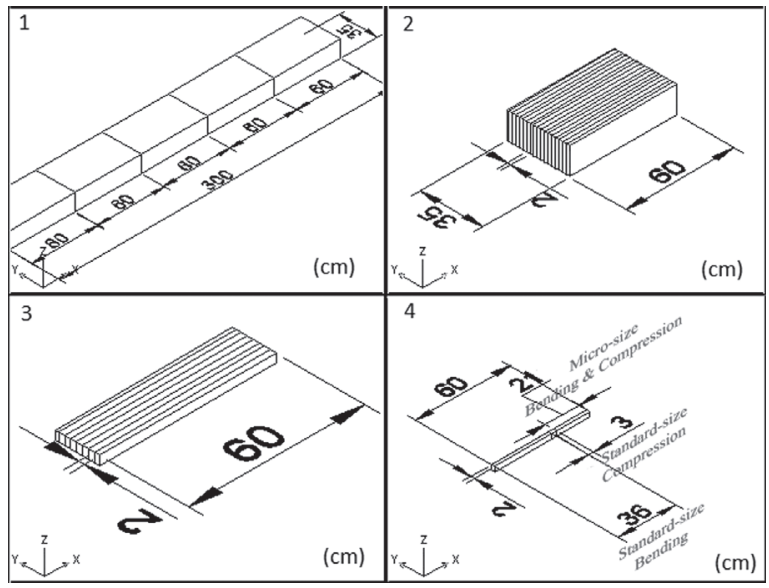

Figure 1a Cutting plan of compression test specimens at standard- and micro-size

Slika 1.a) Plan izrezivanja ispitnih uzoraka standardne veličine i mikrouzoraka za ispitivanje tlačne čvrstoće termine the tensile strength parallel to grain (ISO 13061-6, 2014) and compression strength parallel to grain (ISO/DIS 13061-17, 2014). The standard-size test specimens were prepared in dimensions of $15 \mathrm{~mm}$ $\times 50 \mathrm{~mm} \times 400 \mathrm{~mm}$ for tensile and $20 \mathrm{~mm} \times 20 \mathrm{~mm} \times$ $30 \mathrm{~mm}$ for compression test. A Lloyd universal test machine with a $10 \mathrm{kN}$ load cell was used for the standardsize tests.

Micro-size tests were performed with a Zwick universal test machine using a $100 \mathrm{~N}$ load cell for compression test and a $1 \mathrm{kN}$ load cell for tensile test. The same ISO standards were used as a guide for the microsize specimens. The micro-size tensile test specimens were approximately $50 \mathrm{~mm} \times 5.0 \mathrm{~mm} \times 1.3 \mathrm{~mm}$ and the width of the specimen was reduced to $0.8 \mathrm{~mm}$ with a sanding drum. The gauge lengths were $3 \mathrm{~mm}$ for the micro-size tensile specimens and $280 \mathrm{~mm}$ for the standard-size specimens. Figure 2 shows the microsize tensile test specimens and the preparation process. The dimensions of micro-size compression test specimens were $3 \mathrm{~mm} \times 3 \mathrm{~mm} \times 5 \mathrm{~mm}$. The micro- and standard-size tensile and compression test specimens are shown in Figure 3.

\subsection{Data analyses and statistical methods 2.3. Analiza podataka i statističke metode}

For the tensile and compression strength, all multiple comparisons were first subjected to an analysis of



Figure 1b Cutting plan of tensile test specimens at standard- and micro-size

Slika 1.b) Plan izrezivanja ispitnih uzoraka standardne veličine i mikrouzoraka za ispitivanje vlačne čvrstoće

Table 1 Properties of the sample trees and sampling area

Tablica 1. Obilježja stabala od kojih su izrađeni uzorci i lokacije stabala

\begin{tabular}{|c|c|c|c|c|c|}
\hline $\begin{array}{l}\text { Tree No. } \\
\text { Broj stabla }\end{array}$ & $\begin{array}{c}\text { Diameter of tree at } 1.30 \mathrm{~m} \\
\text { Promjer stabla na visini } 1,30 \mathrm{~m} \\
\mathrm{~cm}\end{array}$ & $\begin{array}{l}\text { Tree age } \\
\text { Starost stabla } \\
\text { Year / god. }\end{array}$ & $\begin{array}{c}\text { Altitude } \\
\text { Nadmorska visina } \\
\mathrm{m}\end{array}$ & $\begin{array}{l}\text { Aspect } \\
\text { Položaj }\end{array}$ & $\begin{array}{c}\text { Slope } \\
\text { Nagib terena } \\
\%\end{array}$ \\
\hline 1 & 33 & 137 & \multirow{8}{*}{1540} & \multirow{8}{*}{$\begin{array}{c}\text { Northeast } \\
\text { sjeveroistok }\end{array}$} & \multirow{8}{*}{40} \\
\hline 2 & 34 & 135 & & & \\
\hline 3 & 34 & 144 & & & \\
\hline 4 & 37 & 127 & & & \\
\hline 5 & 34 & 94 & & & \\
\hline 6 & 32 & 135 & & & \\
\hline 7 & 36 & 123 & & & \\
\hline 8 & 35 & 130 & & & \\
\hline
\end{tabular}






Figure 2 Micro-size tensile test specimens and preparation process

Slika 2. Mikrouzorci za ispitivanje vlačne čvrstoće i proces njihove pripreme

variance (ANOVA) at $p<0.05$ considering two factors (specimen size and individual tree) and interactions. Post-hoc comparisons were conducted using Duncan's multiple range tests. Regression analysis was used to determine the relationship between standard- and micro-size specimens.

\section{RESULTS}

\section{REZULTATI}

The average tensile strength values and Duncan test results of the standard- and micro-size Scots pine wood specimens are shown in Table 2. The tensile strength values of the standard- and micro-size specimens were determined as $76.9 \mathrm{MPa}$ and $91.5 \mathrm{MPa}$, respectively. The results showed that the tensile strength values of the micro-size specimens were $19.0 \%$ higher compared to the standard-size specimens. For individual trees, the tensile strength values ranged from 75.7

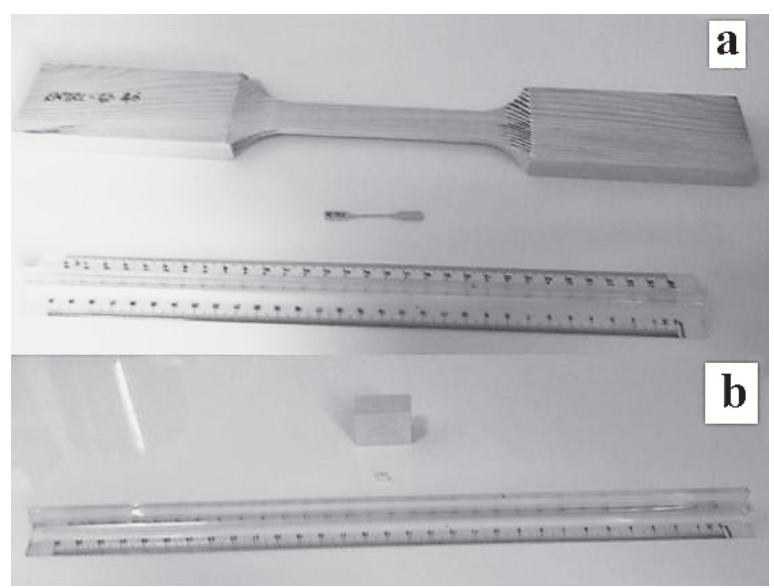

Figure 3 Micro- and standard-size test specimens for (a) tensile and (b) compression

Slika 3. Mikrouzorci i ispitni uzorci standardne veličine za ispitivanje: a) vlačne čvrstoće, b) tlačne čvrstoće

$\mathrm{MPa}$ (tree 2) to $111.8 \mathrm{MPa}$ (tree 6) in the micro-size specimens and from 66.6 $\mathrm{MPa}$ (tree 5) to $89.9 \mathrm{MPa}$ (tree 6) in the standard-size specimens. The highest tensile strength values were observed for tree 6 in both the micro- and standard-size specimens.

The average compression strength values and Duncan test results of the standard- and micro-size Scots pine wood specimens are shown in Table 3.

The compression strength values of standard- and micro-size specimens were found to be $43.8 \mathrm{MPa}$ and 36.3 $\mathrm{MPa}$, respectively. The results showed that the compression strength of the micro-size specimens were $17.1 \%$ lower compared to the standard-size specimens. For individual trees, the compression strength values ranged from $31.9 \mathrm{MPa}$ (tree 2) to $40.9 \mathrm{MPa}$ (tree 6) in the micro-size specimens and from $36.3 \mathrm{MPa}$ (tree 2) to 51.9 $\mathrm{MPa}$ (tree 6) in the standard-size specimens. The highest compression strength values were observed for tree 6 in both the micro- and standard-size specimens.

Table 2 The average tensile strength values and Duncan test results of standard- and micro-size Scots pine wood

Tablica 2. Prosječne vrijednosti vlačne čvrstoće i rezultati Duncanova testa za podatke dobivene na mikrouzorcima i ispitnim uzorcima standardne veličine

\begin{tabular}{|c|c|c|c|c|c|c|}
\hline \multirow{2}{*}{$\begin{array}{c}\text { Tree No. } \\
\text { Broj stabla }\end{array}$} & \multicolumn{6}{|c|}{ Tensile strength, MPa / Vlačna čvrstoća, MPa } \\
\cline { 2 - 7 } & \multicolumn{2}{|c|}{ Standard-size / Uzorci standardne veličine } & \multicolumn{3}{c|}{ Micro-size / Mikrouzorci } \\
\cline { 2 - 7 } & $N$ & Mean & Std. Deviation & $N$ & Mean & Std. Deviation \\
\hline 1 & 32 & $66.9^{\mathrm{a}}$ & 22.4 & 31 & $83.1^{\mathrm{de}}$ & 31.2 \\
\hline 2 & 15 & $74.0^{\mathrm{ab}}$ & 22.6 & 15 & $75.7^{\mathrm{d}}$ & 25.1 \\
\hline 3 & 23 & $85.1^{\mathrm{bc}}$ & 26.9 & 23 & $94.7^{\mathrm{def}}$ & 33.2 \\
\hline 4 & 35 & $83.1^{\mathrm{bc}}$ & 17.5 & 35 & $98.2^{\text {ef }}$ & 36.2 \\
\hline 5 & 25 & $66.6^{\mathrm{a}}$ & 14.7 & 23 & $80.4^{\mathrm{de}}$ & 21.5 \\
\hline 6 & 28 & $89.9^{\mathrm{c}}$ & 24.7 & 27 & $111.8^{\mathrm{f}}$ & 35.0 \\
\hline 7 & 30 & $77.8^{\mathrm{ab}}$ & 19.3 & 28 & $89.9^{\mathrm{de}}$ & 31.8 \\
\hline 8 & 31 & $70.9^{\mathrm{a}}$ & 12.4 & 29 & $89.4^{\mathrm{de}}$ & 33.9 \\
\hline Total & 219 & 76.9 & 21.5 & 211 & 91.5 & 33.1 \\
\hline
\end{tabular}

$N$ - Number of specimens; Groups with same letters in column indicate that there is no statistical difference $(p<0.05)$ between the samples according to Duncan's multiply range test.

$N$ - broj uzoraka; među prosječnim vrijednostima označenim istim slovom u stupcu nije utvrđena statistički signifikantna razlika (p < 0,05) prema Duncanovu višestrukom usporednom testu 
Table 3 The average compression strength values and Duncan test results of standard- and micro-size Scots pine wood

Tablica 3. Prosječne vrijednosti tlačne čvrstoće i rezultati Duncanova testa za podatke dobivene na mikrouzorcima i ispitnim uzorcima standardne veličine

\begin{tabular}{|c|c|c|c|c|c|c|}
\hline \multirow{3}{*}{$\begin{array}{l}\text { Tree No. } \\
\text { Broj stabla }\end{array}$} & \multicolumn{6}{|c|}{ Compression strength, MPa / Tlačna čvrstoća, $\mathrm{MPa}$} \\
\hline & \multicolumn{3}{|c|}{ Standard-size / Uzorci standardne veličine } & \multicolumn{3}{|c|}{ Micro-size / Mikrouzorci } \\
\hline & $N$ & Mean & Std. Deviation & $N$ & Mean & Std. Deviation \\
\hline 1 & 51 & $40.3^{g}$ & 6.1 & 47 & $32.5^{\mathrm{n}}$ & 5.8 \\
\hline 2 & 43 & $36.3^{\mathrm{h}}$ & 5.4 & 42 & $31.9^{\mathrm{n}}$ & 5.7 \\
\hline 3 & 47 & $48.6^{\mathrm{k}}$ & 5.9 & 44 & $39.6^{\mathrm{r}}$ & 6.3 \\
\hline 4 & 61 & $44.9^{1}$ & 7.0 & 59 & $35.8^{\mathrm{pr}}$ & 6.6 \\
\hline 5 & 46 & $40.6^{\mathrm{g}}$ & 6.1 & 45 & $35.2^{\circ}$ & 6.4 \\
\hline 6 & 57 & $51.9^{\mathrm{m}}$ & 7.2 & 55 & $40.4^{r}$ & 7.0 \\
\hline 7 & 41 & $41.3^{g}$ & 5.1 & 40 & $34.1^{\text {no }}$ & 5.0 \\
\hline 8 & 58 & $43.7^{1}$ & 4.2 & 53 & $36.3^{\mathrm{op}}$ & 6.1 \\
\hline Total & 404 & 43.8 & 7.5 & 385 & 36.3 & 6.8 \\
\hline
\end{tabular}

$N$ - Number of specimens; Groups with same letters in column indicate that there is no statistical difference $(p<0.05)$ between the samples according to Duncan's multiply range test.

$N$ - broj uzoraka; među prosječnim vrijednostima označenim istim slovom u stupcu nije utvrđena statistički signifikantna razlika $(p<0,05)$ prema Duncanovu višestrukom usporednom testu

The factors of the specimen size (standard- and micro-size), individual trees (eight trees) and their interactions on the tensile and compression strength are shown in Table 4. For the tensile strength, specimen size and individual tree were significantly different $(p$ $<0.000)$, while the interaction of specimen size and individual tree was not $(p=0.811)$. For the compression strength, all factors were significantly different.

Table 4 The interactions of specimen size and individual tree on tensile strength and compression strength (ANOVA)

Tablica 4. Interakcije veličine uzorka i pojedinačnog stabla na vlačnu i tlačnu čvrstoću (ANOVA)

\begin{tabular}{|c|c|c|c|c|c|c|}
\hline $\begin{array}{l}\text { Source } \\
\text { Izvor }\end{array}$ & & $\begin{array}{c}\text { Type III sum } \\
\text { of squares } \\
\text { Zbroj kvadrata } \\
\text { - tip III. }\end{array}$ & $d f$ & $\begin{array}{l}\text { Mean square } \\
\text { Kvadrat srednje } \\
\text { vrijednosti }\end{array}$ & $\boldsymbol{F}$ & $P$ \\
\hline \multirow{3}{*}{$\begin{array}{l}\text { Tensile } \\
\text { Strength } \\
\text { vlačna čvrstoća }\end{array}$} & Specimen size / veličina ispitnog uzorka & 18692.1 & 1 & 18692.1 & 26.28 & 0.000 \\
\hline & Individual tree /pojedinačno stablo & 34072.4 & 7 & 4867.5 & 6.84 & 0.000 \\
\hline & $\begin{array}{l}\text { Specimen size * individual tree } \\
\text { veličina ispitnog uzorka * pojedinačno stablo }\end{array}$ & 2644.8 & 7 & 377.8 & 0.53 & 0.811 \\
\hline \multirow{3}{*}{$\begin{array}{l}\text { Compression } \\
\text { strength } \\
\text { tlačna čvrstoća }\end{array}$} & Specimen size / veličina ispitnog uzorka & 10571.7 & 1 & 10571.7 & 284.1 & 0.000 \\
\hline & Individual tree / pojedinačno stablo & 11217.9 & 7 & 1602.6 & 43.1 & 0.000 \\
\hline & $\begin{array}{l}\text { Specimen size * individual tree } \\
\text { veličina ispitnog uzorka * pojedinačno stablo }\end{array}$ & 829.1 & 7 & 118.4 & 3.2 & 0.003 \\
\hline
\end{tabular}



Figure 4 Regression analysis results for tensile strength of micro- and standard-size wood specimens

Slika 4. Regresijska analiza rezultata vlačne čvrstoće mikrouzoraka drva i ispitnih uzoraka standardne veličine 


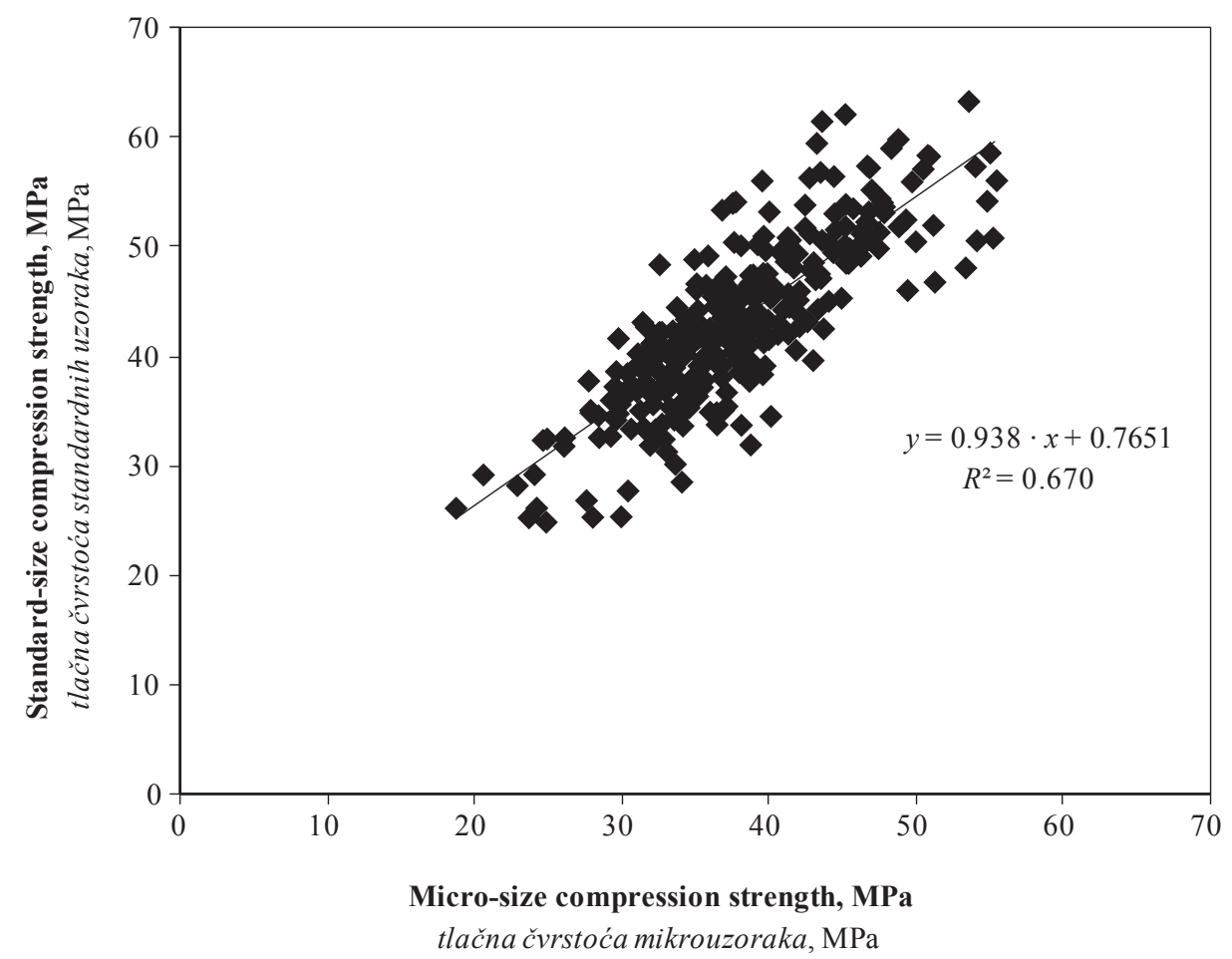

Figure 5 Regression analysis results for compression strength of micro- and standard-size wood specimens Slika 5. Regresijska analizira rezultata tlačne čvrstoće mikrouzoraka drva i ispitnih uzoraka standardne veličine

Regression analysis graphics for the tensile and compression strength of the micro- and standard-size wood specimens are shown in Figures 4 and 5, respectively. The regression analysis indicated that all measured properties of the micro-size specimens were significantly correlated with the standard-size specimens $(p<0.000)$. The tensile and compression strength values of the standard- and micro-size specimens showed a positive linear dependency, presenting coefficients of correlation of 71.0 and 81.9 percent, respectively, in linear regression models.

\section{DISCUSSION \\ 4. RASPRAVA}

In previous studies about the tensile strength of micro-size test specimens, researchers determined the tensile strength value of some wood species. Cai et al., (2007) determined that the tensile strength values of yellow poplar, loblolly pine, willow and red oak wood strands were 48.5 MPa, 58.7 MPa, 22.7 MPa and 40.7 $\mathrm{MPa}$, respectively. Additionally, the tensile strength of southern pine strands was determined as $50.0 \mathrm{MPa}$ (Wu et al., 2005), of loblolly pine strands as $43.3 \mathrm{MPa}$ (Hindman and Lee 2007) and of yellow poplar strands as $70.3 \mathrm{MPa}$ (Hunt et al., 1989). The gage length, sample thickness, loading rate and sample shape (dogbone or rectangle shape) affect tensile strength of micro-size samples. Unlike previous studies, in the current study, micro-size tensile strength specimens were prepared in the dog-bone shape. Kohan et al., (2012) compared the tensile strength and modulus of elasticity of rectangular and tapered (dog-bone) wood strands. They concluded that the dog-bone shaped specimens had $16 \%$ and $27 \%$ higher tensile strength and modulus of elasticity, respectively, than the rectangular specimens, and that the variation in mechanical properties was not statistically different for the two shapes. The higher tensile strength value in the microsize specimens could be attributed to the dimensions of the specimens, loading rate, ratio of earlywood and latewood or gauge length. Jeong (2008) pointed out that the results of previous studies are not directly comparable because of different loading conditions and different wood species. In his study, he indicated that the tensile strength of micro-size loblolly pine wood specimens reported by Hindman and Lee (2007) was $36 \%$ higher compared to the work of Cai et al., (2007). This comparison clearly shows the effect of specimen dimensions and loading rate on the strength properties of micro-size specimens. Price (1976) concluded that tensile strength increased as gauge length increased. Jeong et al., (2008) concluded that tensile strength and MOE generally increased as the thickness increased, and the thickness of the specimen wood strands significantly affected the tensile strength and MOE of southern pine wood. In order to decrease the variability of test results, they recommended a $0.254 \mathrm{~mm} / \mathrm{min}$ loading rate and a strand thickness of between 0.794 and $1.91 \mathrm{~mm}$.

The results showed that the tensile strength value of the micro-size specimens was higher than that of the standard-size specimens. This is compatible to Weibull's theory, which states that with increasing volume, the strength decreases. Schneeweiß and Felber (2013) mentioned a strong decrease in tensile strength when increasing the length of the specimens. Conversely, previous studies have stated that the tensile strength of micro-size specimens was lower than that of standard- 
size specimens (Price 1976; Cai et al., 2007). Cai et al., (2007) reported that the tensile properties of willow, yellow poplar, red oak, and loblolly pine wood strands were significantly lower than those of standard-size. When compared to the tensile strength of standard-size specimens in Wood Handbook, those of wood strands from willow, yellow poplar, red oak, and loblolly pine were lower by $31.1 \%, 44.2 \%, 36.2 \%$ and $73.4 \%$, respectively. Price (1976) observed similar results for microsize sweet gum specimens. In previous studies researchers compared their findings with published values in Wood Handbook (Green et al., 1999) for the same wood species. This approach of comparing the values obtained from different trees is not valid for obtaining information about the presence of a correlation between microsize and standard-size samples. It is recognized that tree age and growth conditions such as climate, soil characteristics, slope and altitude affect the annual ring width and the mechanical properties of wood.

The results of the present study showed that the compression strength value of the micro-size specimens was lower compared to the standard-size specimens. Similar results were seen by Zink-Sharp and Price (2006) in sweet gum (Liquidambar styraciflua L.), yellow poplar (Liriodendron tulipifera) and maple (Acer rubrum) wood. They found that the compression strength of the micro-size specimens was close to but lower than handbook values for all studied species. They explained that the exact cause of this difference was unknown, but that there were at least two probable explanations. The size effect was one possibility and the second was that damage created by specimen preparation had a more significant impact on the intra-ring specimens than on the standard-size specimens. Another reason of the differences between the compression strength of micro- and standard size samples can be the failure mode. Schlotzhauer et al., (2015) concluded that the mode of failure is also affected by the specimen dimensions.

The compression strength results of the present study are contradictory to Weibull theory. Schneeweiß (1964) concluded that the volume strength dependence is a function of absolute specimen volume. He established three different categories. At volumes below 10 $\mathrm{cm}^{3}$ (Category 1) and above $1000 \mathrm{~cm}^{3}$ (Category 3), Weibull's theory applies. In between (Category 2), the volume is considered an influencing factor of low importance. Schneeweiß (1964) stated that the compression strength of Spruce wood first decreased with increasing specimen volume then increased slightly to maximum and finally decreased again. Madsen and Buchanan (1986) stated that the size effect is dependent on wood species. Schlotzhauer et al., (2015) observed that the compression strength increased as specimen volume increased in beech, oak and lime wood, while the specimen dimensions did not influence the compression strength of maple, birch and ash wood.

\section{CONCLUSIONS}

5. ZAKLJUČAK

Based on this study, the following conclusions can be drawn:
1. The compression strength of the micro-size specimens were $17.1 \%$ lower compared to the standardsize specimens, while tensile strength was $19.0 \%$ higher in micro-size specimens.

2. The effects of specimen size, individual trees and the interactions between size and trees on tensile and compression strength were statistically significant, except for the effect of the interaction of specimen size and individual trees on tensile strength.

3. The regression analysis indicated that tensile and compression strength of the micro-size specimens was significantly correlated with the standard-size specimens. A positive linear regression between the micro- and standard-size specimens was found for tensile and compression strength.

4. Micro-size test specimens can be used to estimate the standard-size test results for the tensile and compression strength of Scots pine wood.

5. Dog-bone shape micro-size tensile strength samples at given dimensions can be used to determine tensile strength of wood. For the loading rate, ISO standards can be used as a guide for the micro-size specimens.

\section{Acknowledgement - Zahvala}

This work was supported by the Scientific and Technological Research Council of Turkey (TUBITAK Project Number: 1120815).

\section{REFERENCE}

\section{LITERATURA}

1. Cai, Z.; Wu, Q.; Han, G.; Lee, J. N., 2007: Tensile and thickness swelling properties of strands from Southern hardwoods and Southern pine: Effect of hot-pressing and resin application. Forest Products Journal, 57(5): 36-40.

2. Deomano, E. C.; Zink-Sharp, A., 2004: Bending properties of wood flakes of three southern species. Wood Fiber Sci., 36(4): 493-499.

3. Groom, L.; Shaler, S.; Mott, L., 2002: Mechanical properties of individual southern pine fibers. Part III. Global relationships between fiber properties and fiber location within an individual tree. Wood Fiber Sci., 34(2): 238250.

4. Hindman, D. P.; Lee, J. N., 2007: Modeling wood strands as multi-layer composites: bending and tension loads. Wood Fiber Sci., 39(4): 516-526.

5. Hunt, M. O.; Triche, M. H.; McCabe, G. P.; Hoover, W. L., 1989: Tensile properties of yellow-poplar veneer strands. Forest Products Journal, 39(9): 31-33.

6. Jeong, G. Y., 2008: Tensile properties of loblolly pine strands using digital image correlation and stochastic finite element method. Doctoral dissertation, Virginia Polytechnic Institute \& State University, Blacksburg, VA.

7. Jeong, G. Y.; Zink-Sharp, A.; Hindman, D. P., 2009: Tensile properties of earlywood and latewood from loblolly pine (Pinus taeda) using digital image correlation. Wood Fiber Sci., 41(1): 51-63.

8. Kohan, N.; Via, B. K.; Taylor, S., 2012: A comparison of geometry effect on tensile testing of wood strands. Forest Products Journal, 62(3): 167-170. https://doi.org/10.13073/0015-7473-62.3.167.

9. Madsen, B.; Buchanan, A. H., 1986: Size effects in timber explained by a modified weakest link theory. Can. J. Civil Eng., 13(2), 218-232. https://doi.org/10.1139/186-030. 
10. Mott, L.; Groom, L.; Shaler, S., 2002: Mechanical properties of individual southern pine fibers. Part II. Comparison of earlywood and latewood fibers with respect to tree height and juvenility. Wood Fiber Sci., 34(2): 221-237.

11. Plagemann, W. L., 1982: The response of hardwood flakes and flakeboard to high temperature drying. Master's thesis, Washington State University, Pullman, WA.

12. Price, E. W., 1976: Determining tensile properties of Sweetgum veneer flakes. Forest Products Journal, 26(10): 50-53.

13. Schlotzhauer, P.; Nelis, P. A.; Bollmus, S.; Gellerich, A.; Militz, H.; Seim, W., 2015: Effect of size and geometry on strength values and MOE of selected hardwood species. Wood Material Science \& Engineering. https://doi.org/10.1080/17480272.2015.1073175.

14. Schneeweiß, G., 1964: Compressive strength and Hoeffgen Hardness. Holz als Roh-und Werkstoff, 22 (7), 258264. https://doi.org/10.1007/BF02608291.

15. Schneeweiß, G.; Felber, S., 2013: Review on the bending strength of wood and influencing factors. American Journal of Materials Science, 3(3), 41-45.

16. Weibull, W., 1939: A statistical theory of the strength of material. Proc. Roy. Swedish Inst. Eng. Res., 45 p.

17. Wu, Q.; Cai, Z.; Lee, J. N., 2005: Tensile and dimensional properties of wood strands made from plantation southern pine lumber. Forest Products Journal, 52(2): 1-6.
18. Zink-Sharp, A.; Price, C., 2006: Compression strength parallel to the grain within growth rings of low density hardwoods. Maderas: Ciencia y Technologia, 8(2): 117 126. https://doi.org/10.4067/S0718-221X2006000200005.

19. ISO 13061-6: 2014: Physical and mechanical properties of wood: Test methods for small clear wood specimens. Part 6: Determination of ultimate tensile stress parallel to grain. International Organization for Standardization, Geneva, Switzerland.

20. ISO/DIS 13061-17: 2014: Physical and mechanical properties of wood: Test methods for small clear wood specimens. Part 17: Determination of ultimate stress in compression parallel to grain. International Organization for Standardization, Geneva, Switzerland.

\section{Corresponding address:}

Assoc. Prof. ÜMIT BÜYÜKSARI, Ph. D.

Duzce University

Faculty of Forestry, Forest Industrial Engineering 81620, Düzce, TURKEY

e-mail: umitbuyuksari@duzce.edu.tr 